\begin{tabular}{|c|c|}
\hline & Volume \& Issues Obtainable at The Women University Multan \\
Annals of Social Sciences and Perspective \\
ISSN: 2707-7063, Volume 1, No.2 December 2020 \\
\hline
\end{tabular}

\title{
Mughal Rulers' (1526-1707) Religious Tolerance Policy and its Impacts on the Society of Sub-Continent
}

\author{
Fariha Kanwal' ${ }^{1}$, Fatima Ali $^{2}$
}

\begin{abstract}
Religious tolerance means that allow people to live their lives according to their personal beliefs, respect for other's opinions, positively understand their ideas, given religious freedom. Unfortunately, there is a lot of religious intolerance in the world which causes many chaos and conflicts, especially the image of Islam became negative due to some terrorist activities. But Islam is the greatest revolution in the world which gives rights to everyone to live their life according to their beliefs. In the sub-continent, after the war of independence of 1857, the Hindus and Sikhs were creating great chaos for the Muslims. They made Muslim's life worst even the Muslims could not live according to their teaching of Islam. So, religious tolerance is compulsory for everyone to live in peace even they are Muslims or not. The research by using the deductive method of research focuses on the policy of religious tolerance of great Mughal emperors that great Mughal emperors from Babur to Aurangzeb showed great religious tolerance under their rule. It is the need of a time because there are many misconceptions about their religious policies and religious tolerance towards different communities of other religions, castes, and sects. And to know about the religious tolerance, behavior and activities of Mughal emperors is necessary. Research is an effort to solve different problems systematically. Basic approaches of research qualitative and quantitative are used for this research to collect data and analyze the data. The fundamental research is initiated with the deductive approach. The data for research collect through primary and secondary sources such as books, journals, government records, articles and reports to analyze the religious intolerance of Mughal emperors.
\end{abstract}

Keywords: Religious tolerance policy, Mughal Rulers, subcontinent, Islam, Non-Muslim communities.

\section{Introduction}

The Mughal period started a new era to bring a change in the sub-continent, socio-culturally, politically, economically and religiously. There were impacts of Mughal religious tolerance on every aspect of life. They recognized the legitimacy of Islamic political power in various secretarial castes and creeds. The founder of the Mughal Empire was Zahir-ud-din Babur, who was a Chagatai Turkish ruler, defeated Ibrahim Lodhi in 1526 in the battle of Panipat. After his death, his son Humayun ruled from 1530-1556, between that period, from 1530-1550 Sher Shah Suri ruled here. They showed great religious tolerance to maintain peace and order and bring harmony among the different communities of different religious sects under their rule.

\footnotetext{
${ }^{1}$ MPhil Scholar, Department of History \& Pakistan Studies, The Women University, Multan

${ }^{2}$ Lecturer, Department of History \& Pakistan Studies, The Women University, Multan
} 
When Babur conquest the sub-continent, there were five independent Muslim rulers two Hindu rulers. Many Rajas were also lived there in hills and jungle sides. Some were obedient towards Muslim rulers and some not, because of their places and remoteness. Babur and Humayun, Akbar (1556-1605) and Jahangir (1605-1627), Shahjahan (1628-1658), and Aurangzeb Alamgir(1658-1707), all had shown religious tolerance in their way and styles. Their intentions behind taking their religious policies towards the indigenous people were positive, as concerned Akbar's religious policy, which main motive was to promote harmony, to brought friendly and cooperated relations among different religious communities. It's just like a brotherhood to live their life peacefully among different communities. There is a misconception about Aurangzeb Alamgir religious tolerance. His religious policy had based on simplicity, which shows his religious tolerance in a balanced way in every matter on an equal basis. His intention was also positive, he just wanted to promote the socio-cultural morality of his subjects and to maintain peace and order in his empire. These emperors have never taken any such kind of action on a religious basis but personally. They selected non-Muslims on merit. They celebrated their festivals as well. Their period of the ruling was progressive and prosperous and one of the main objects was to adopt the behavior of religious tolerance. So, religious intolerance is the main factor to create chaos in society. Where ever it did not show from the extremists, we can see peace and harmony which prevailing in the society. Mughal emperors did not show any such kind of religious intolerance that we are facing nowadays. As we take religious intolerance in Pakistan or the whole world, there are many communities. They belong to different religions, show religious intolerance. They try to insight and insult one another on a religious basis. And it became the biggest cause of terrorism. The non-Muslim community does not want to see again the Muslim supremacy or their role in progress in a positive way. They want to smash them. So, we must analyze those factors which are responsible for our decline, in which religious intolerance is the main factor and we must have to improve the image of Islam in a positive way that Islam is the name of peace and harmony, not terrorism. If there is religious intolerance, there would be a lack of security and then there will be no peace and harmony in a society. If there is terrorism, there should be no creativity and developments. So, we re-organize ourselves for maintaining peace and order in a society. We have to give rights, fair justice, to the minorities, give them protection, and religious tolerance has to be promoted. There should be religious tolerance among the different communities who lived in the world. Wherever religious tolerance shows, it brings peace and harmony. In Spain, Ottoman Empire, or such as India, the people of these areas lived poor life under the cruel rulers, they want to relieve from such kind of rule where they lived like a slave. So, they invited Muslims to invade here to conquered and guarantee them free life where no restrictions, no injustice, would be happened. The great Mughal empire was one of the glorious and peaceful empires of that time living among different other non-Muslim communities. Muslims were at their peak, and especially Akbar, who shows great religious tolerance under his rule, proved peace and harmony among the different communities. The Mughal emperors always encouraged nonMuslims in Mughal services. They promoted Hindi Sanskrit literature and music, art and culture. They adopted their dresses and many festivals and ceremonies. They married Hindu Rajputs women and gave them full freedom to live their lives according to their faiths. These Mughals fought their aims and interests, not on a religious basis. Babar fought Ibrahim Lodhi, who was Muslim, not Hindu, it shows that they never fight on a religious basis but for their gains. They always established friendly relations after the conquest. It should be said that it was religious tolerance of Mughals that they ruled successfully and that it was also the result of their religious tolerance that there is an amalgamation of culture and traditions of other communities in Muslim culture, especially Hindu culture. These emperors have never taken any such kind of action on a religious basis but personally. Their period of ruling was progressive and prosperous. The main factor was to adopt the policy of religious tolerance. Due to this religious 
tolerance, other non-Muslim communities have given chances to show their ability in the administrative structure, art, and literature, etc. and the Mughal emperors always encouraged their work and services. Their policy is based on Islamic principles. Muslim state was theocratic and the King was the representative and agent of God Almighty. The civil authorities are bound to enforce law and order in a society. The Muslims pay Zakat and other kinds of taxes. On the other hand, the Hindu subjects must pay jizya. It means that the Muslim rulers would be responsible to protect their lives and property etc. These emperors were too much indifferent towards spiritual affairs, too much engrossed in schemes of conquest and administration to undertake the task of conversion in earnest. Their power was in a large measure dependent on links with the Rajput prices. The native princesses whom they married brought a stain of Hindu blood into the royal line and promoted tolerance of Hinduism. Their religious tolerance policy is to avoid the crisis and to build a strong center. It has been analyzed that Akbar's intention was positive in the reference of his Din-e-Elahi. Akbar realized that whenever there would be chaos in a society, it should be removed with the implementation of such kinds of laws which created a favorable condition of peace and harmony. So, after a long discussion, he decided to adopt all good things for every religion and make a brotherhood among them. And we can say that his intention was positive and he proved for his successful ruling due to maintaining peace and order.

We should have to create harmony among the socio-religious differences in society. Positive Role of social media and technology, even there should be a change in our thoughts, we have too broad-minded in our thinking, morality should be courage in society, to increase awareness about the Islamic law in which brotherhood must be introduced implemented. There should be the proper implementation of law and order in a society. Positively show our Islamic tradition. We have to remove the negative impact on the image of Islam. But the lawlessness in the country makes society's condition worst. We have to bring about institutional changes that turn Pakistan into a modern and prosperous country.

The Arab conquest of the Sub-continent had great impacts on Sub-continent. It cannot be denied that the Arab conquest of the sub-continent sowed the seed of Islam which brought about the homeland of our 'Pakistan'. A large number of persons in the sub-continent were converted to Islam. Arabs opened India to the rest of the world and the noble tenets of Islam. They taught a lot and learned a good deal. Arabs influenced the political, religious, social, and sociological life of the sub-continent. These marks are clearly visible on the language, dress, customs and every aspects of life in sub-continent.

When the Arabs settled in the sub-continent, they were dazzled by the ability of the Inhabitants of their land. Hindu learning also was encouraged by the ministerial family of Barmaks during the Khilafat of Harun from 786 to 808 A.D. They invited Hindu scholars to Baghdad and ask them to translate books of Sanskrit on medicine, philosophy, etc., into the Arabic language. They also put the Hindu physicians in charge of their hospitals.

In the $11^{\text {th }}$ century, Al-Biruni had visited India, who made the just, fair, and sympathetic study of Hindu society and its culture. He describes in his book, Kitab-ul-Hind, that the Hindus called the foreigners, mleccha i.e. impure. They had forbidden to contact them and did not make any kind of relation. They were different from Muslims in every aspect of life. Al-Beruni shows a tolerant attitude in describing the Hindu society. He studied deeply their religion, superstitions, their food, dresses, law, and customs in detail. When another traveler, Ibn Buttuta visited the Indo-Pak subcontinent in 1030 A.D. he also observed a fair and humane attitude towards the subjects from the ruling class. 
After the Ghurid occupation of northern India also the Hindu religious thinkers were obliged to face the changed circumstances by effecting a change in their religious outlook. Hinduism gave evidence of great dynamics when it modified its social outlook and religious behavior according to the requirements of the time. The rigidity of the caste system was softened in the centuries that followed and Hinduism which did not believe in making converts adopted proselytizing methods. Though the Bhakti movement, which was based on the two revolutionary doctrines of a direct approach to Ultimate Reality and brotherhood of man blossomed in the $14^{\text {th }}$ century. Probably never in the annals of Hinduism religious leadership had sprung from that class of society to which saints like Kabir, Nanak, Dadu, Dhanna, and others belonged. A comparison and contest of the religious and social outlook of the Hindus in the $12^{\text {th }}$ and the $15^{\text {th }}$ centuries will explain the nature and extent of the influence of Islam on Indian culture.

\section{Influence of Islam:}

The word "tolerance" was firstly used in the 15th century. It is derived from endurance and fortitude which were used in the 14th century. According to the Etymology Dictionary, this word was first to use to describe having permission from authorities in 1550. The term toleration is constructed from the Latin word 'tolerate', means to the optimist, expression, and suffer. It considered the acceptance of other's faiths, practices, either these are right or wrong, but bear by the authorities. Anton Hein says that it is the awareness of the rights of others and gives freedom to their own beliefs, faiths and practices.

The influence of Islam in the sub-continent was great. Islam prevailed by Muslims on a great level. It was the main effect on indigenous people of the sub-continent. They were mostly idolaters and many of them accepted Islam by the kind and humble behavior of Muslims. But the Muslims never forced them to accept Islam. They give them full religious freedom to live their lives according to their beliefs. These Mughal emperors showed them religious tolerance.

\section{Support by Hindu Rajas:}

In private and daily routine life, the Mughal emperors had always favored the Hindu Rajas and Nobles. They joined them freely in their festivals and feasts. They wanted to create love and peace due to the policy of tolerance. Due to their religious tolerance policy towards different non-Muslim communities, they became supporters of the Mughal Empire.

\section{Non-Muslims in Mughal Services:}

The services opened for all Indians without any discrimination. The people could get services in the Mughal Empire based on their talent. And when we talk about their less participation in the Mughal state was because of their moral degeneration and intellectual ignorance, not because of the religious basis. Afterward, Hinduism had many mystics, scholars and Intellectuals. They had the freedom to express their feelings and ideas. They were independent to utilize their abilities. The Faithful service and submissive department were their chief recommendations. The higher services, especially in the army, were monopolized by the Rajputs to the exclusion of other Hindu castes. The subordinate civil services fell to the lot of Khastris from the Punjab, Agarwal Banias, Kayasthas and others. The predominance of the Rajputs in the Mughal service was actuated by matters of policy and was a diplomatic stroke, pure and simple, as they formed the cream of Hindu society and their loyalty and submission meant the acknowledgment of the Muslim rule by the Hindu population in general. Raja Todar 
Mal, who was distinguished for foresight and mental activity, was directed to go and examine the methods of ingress of the fort, and to submit a report as to how it could best be taken. Sir Tomas Roe was the first ambassador of England to the Mughal court. As there were Muslim writers in Hindi poetry, there grew up Hindu writers of Persian and Urdu poetry. They became the friends of the Mughal rulers and it was a good effect on the Mughal rulers. They favored them in every matter.

\section{Titles are given to Non-Muslims:}

- Hindu Nobles

- Hindu Musician

- Christian painters

The imperial system was open to all Muslims as well as to prompted the non-Muslims. Everyone had allowed the participation in the Mughal services. They appointed them higher posts of political and military services, as well as they, adopted their culture to promote peace and security in society. They gave them titles for their bravery and loyalty. Anup Ray fought against a tiger and saved the life of the Emperor was given the title of Sang-dalan (Crusher of the lion). Indian musicians used the tradition of the Hindu instruments and gave many titles like Surgian Khan, Sarud Khan, etc. These all were to encourage their abilities. This effect was creating a pleasing change in the atmosphere of the sub-continent where different religious sects lived. That shows the religious tolerance behave of these Mughal Emperors towards nonMuslims.

\section{Mughal Ruler's Humble Behavior to Non-Muslims:}

The Mughal Emperors never took revenge on the non-Muslims. They had always their grudge or interests. The Mughal emperors forgave the mistakes of Muslim people as well as Hindus after taking forgiveness from the emperors. They became their faithful and dutiful persons. So, there was a great effect due to their humble and kind behavior towards non-Muslims.

\section{Alliance with Hindu Rajputs:}

The alliance of the Rajputs with the Mughals roused the religious conscience of the former as little as it did that of the latter. Some Hindus even accepted innovations of political significance and made them part of their religious rituals. There were Rajput nobility and the Hindu majority population. In the Mughal court, everyone had allowed to complain and demand justice from them. The Mughal court holds regular for their subjects to listen to their voice directly. These alliances create harmony among them.

\section{Charities and Rewards are given by Mughal Rulers to Non-Muslims:}

The Mughal Emperors gave charities to their poor subjects without any discrimination of religion. It is also to create loyalty for their rule. Under their rule, political loyalty was increased due to religious tolerance. They were not against the Hindus but their some customs, which were hateful and dangerous for the peoples.

\section{Matrimonial Relations:}

Akbar married the Hira Kunwar Sahiba Harka of Bai "Maryam al-Zamani”, mother of Jahangir. Other wives were the daughter of Raja Bihari Mal of Amber, niece of Raja Kalyan Mal of 
Bikaner, daughter of Raja Har Rai of Jaisalmer, Daughter of Raja of Dungarpur Hindus.

Jahangir is also married to the daughter of Raja Bhagwan Das and the father of Raja Man Singh. Other wives are Jagat Gosain Manmati, daughter of Raja Udai Singh, son of Mal Deo of Mewar, mother of Khurrum "Shajahan". Shajahan married Bhai Lilaviati, Daughter of Rao Sakar Singh. Aurangzeb also married the daughter of the Rajah Raju of Rajauri. All these married also showed a tolerant attitude towards the non-Muslims ladies and gave them all rights. It should be noticed that the emperors like Jahangir, Shahjahan, Auranzaib were the son of these ladies.

\section{Adopted Hindu and Persian Culture:}

- Their dresses

- Their superstitions

- Their customs

These Mughal emperors adopted the Hindu and Persian culture, their dresses, superstitions, customs, etc. The amalgamation of culture and tradition had a great effect on the sub-continent.

\section{In the Ceremonies and Festivals:}

The Mughal emperors always participate in the ceremonies and festivals of the indigenous people with great zeal. Hindu festivals were regularly celebrated at the court. They enjoyed many non-Islamic festivals and ceremonies which shows their religious tolerance behavior. Such as:

- Festival of Holi

- Festival of Nauroz

- Festival of Diwali

- Festival of Dasehra

- Festival of Basant

- Mina Bazaar

They supervised many Persian and Indian festivals which they celebrated such as the festivals of Nauruz, Holi, Diwali, Dasqhra, Basant, Mehrjan, Jashn-i-Wazn, Jashn-i-Sihhat, Jashn-iGulabi, Jash-i-Tajpushi, Jashn-i-Mahtabi and Jashn-i-Fath. Because they thought that these celebrations brought a change in the life of the people. They realized the importance of these festivals. They wanted to impress their subjects. They wanted peace, security and prosperity in Muslim states. They give them symbols of royalty to their Nobles. They received their ambassaders of different kingdoms with great grandeur, which promoted their friendly relations and solved many commercial problems due to the behavior of religious tolerance. They always took much attention to the condition of their country. They had made their friendly relations and solved many commercial problems due to the behavior of religious tolerance. They always took much attention to the condition of their country. They had made their subjects happy. For this purpose, they hold their court many times in a day. They discussed their matter after the prayer time.

Many other traditions are adopted from Hindu culture, in which Mehndi and Barat ceremonies and the Turkish tradition Sachaq. They celebrated those occasions with great zeal. They also adopted the dress of Turkish and Rajput styles. Due to this, they understand each other. 
The Mughal court was the center of the social gathering, where all matters were attempted. Every day was fixed for meetings with some personalities, and the days of Saturday and Thursday for ahl-i-Sadat, who was the protector of religion. During their glorious period, art and architecture, learning and literature, painting and music made great progress.

The Mughal emperors provided the chances to the people to understand their social, political, and religious problems. They gave them opportunities to convert their grievances into happiness. For this purpose, they had directly linked with their subjects in the shape of festivals and outdoor pastimes, in which they hunted, playing polo, and also entertained themselves with wrestlings, witnessing tricks of jugglers, pigeon flying, etc. Mina bazaar also organized for the amusement of the people that was the social contact to direct their emperors, where they had to listen to their problems and gave them solutions.

\section{Mughal Schools were Secular:}

The Mughal schools of painting and architecture were secular. Everyone was could come to learn there without any discrimination of religion. Hindus, especially Rajputs learned many things from the Muslims. Their libraries were also arranged according to their subjects. Many Indian books translated from Sanskrit into Persian.

\section{Promotion of Secular Art Learning:}

Under the Mughal rule, the nobles, rich or poor, every scholar who belong to any religion, participated with the same interest and zeal to promote the growth of art and learning. Education was free for any person without any discrimination. Secular and non-secular education had been taught in schools or mudarssa at that time. Due to this, people became broad-minded and to know about the knowledge of one another and took advantage to make their ruling progressively.

\section{Muslim-Hindu Interaction:}

The interaction of Islam and Hinduism did not operate in one direction only. Muslim society was also deeply influenced and purely local influences left a mark, at least temporarily, on Islam in the Subcontinent. Some western writers have been stated that it was influenced by Hinduism as well as Islam. They seem to assume that Islam in India was originally pure and orthodox, but due to Hindu influences absorbed many un-Islamic features.

\section{Prevalence of Peace and Order:}

There were some examples of the prevalence of peace and order in a sub-continent in the reign of the Mughals. Under their rule, every person was peaceful and prosperous and free and independent and everyone had obeyed him. The people dwelt in repose and safety, and obedience and loyalty.

\section{Promotion of Communal Harmony:}

There was the promotion of communal harmony among the different religious communities due to the religious tolerance of the great Mughals. 


\section{The amalgamation of Culture:}

The Mughal emperors increased friendly relations with non-Muslims which prove to be flourished the different civilizations and that was the amalgamation of cultures.

\section{Stability of Mughal Empire:}

The great Mughal emperors did hard work to achieve their destiny and made a very strong and prosperous Empire under their rule. They were the descendants of Timur, who was a great conqueror of his time. The Mughals restore peace and order in a society. They were intelligent and clever statesmen and military genius. They were firm believers in Allah, lover of nature, seeker of truth, fond of arts. They were affectionate father, generous friends, a kind master to their subjects. They were broad-minded, bold and tolerant rulers. They were wise and enlightened rulers. The military system formed the Mughal nobility without any discrimination of religion, sects, caste and creed. They promoted them to higher ranks due to their bravery and faithfulness, which gave strength to the Mughal Empire. The central administration became strong due to this act. There were made great military expansions in which Muslims and nonMuslims both participated equally without any discrimination of religion, caste and creed,etc.

\section{The Prosperity of Land and People:}

The Mughal emperors maintained close and friendly relations with also the neighboring countries of Turkey, Turan and especially with Iran. The migration of scholars, merchants, Sufis, architects, engineers, poets, adventurers encouraged their talent, which makes their Empire prosperous. Working toleration developed among the indigenous people. They won the hearts of the subjects. The cooperation of indigenous people on welfare and other works was to be proved a good effect on them.

\section{Conclusion:}

The impacts of fair dealings and the wisdom policies of the Mughal emperors had proved a great thing for their government. That was all due to their religious tolerance policy. He had relied on non-Muslims leaders like Muslim leaders and this unique technique was liked by all the people of that time. Roop-Singh, Jasoonat-Singh and Raja Jay Singh were brave and popular fighters of Shah Jahan's army. Muslim leaders were carrying orders of Hindus and Rajputs were obeying orders of Muslim leaders considering each other as one part of a strong army. This was the wonderful result of Mughal's useful policies.

Due to this religious tolerance, other non-Muslim communities have been given chances to show their ability in the administrative structure, art and literature, etc. and the Mughal emperors always encouraged their work and services. It can be the judge that wherever Muslims showed religious tolerance towards other non-Muslim communities, there had been peace and order in society either in Spain or in an Ottoman empire of Muslims. And we can see that nowadays, religious tolerance is replaced by religious intolerance, which caused so much chaos and disturbance among the different communities.

All of these happened due to the religious tolerance policy of the Mughal rulers. In every aspect of life, they encouraged non-Muslims in their life. So, therefore, their religious tolerance attitude towards non-Muslims had created positive impacts. 


\section{References}

Humayun-Nama by Gulbadan Begum Rasheed Akhtar Nadwi (Urdu translator), Sang-e-Meel Publictaions, Lahore, 1995, p. 41

Humayun-Nama, by Gul-Badan Begum Annette S. Beveridge (translator),Sang-e-Meel publications, chowk urdu bazaar, Lahore, Pakistan,1987,p.111

Ibid, p. 108

Ibid, p. 27

Ibid, p. 711

Irfan Habib and K. A. Nizami, Muslims in India, (a miscellany, Vol.3), book traders, Lahore, Alhamra Press, Lahore, 1854, p. 137

Ishtiaq Husain Qureshi, The Muslim Community of the Indo-Pakistan subcontinent(610-1947), Bureau of composition and translation university of Karachi, Pakistan, 1999, p. 109

Ishtiaq Husain Qureshi, The Muslim Community of the Indo-Pakistan subcontinent (610-1947), university of Karachi, Karachi, 1999, p. 46

Maj. (R) Prof. Muhammad Tariq Awan, History of India and Pakistan, vol.1, Moenjodaru Cadet College, Larkana,1947, p. 27

Mstafa Waheed, printed, Islamia Al daudia printers,Lahore, Pakistan, p 24 Mubarak Ali, the Mughal court, op. cit, p. 59

Muhammad Tariq Awan, History of India and Pakistan, vol.1, Moenjodaru Cadet College, Larkana, 1947, p. 21.

Muhammad Yasin, A social history of Islamic India, op. cit, p.48. 